\title{
Introductory works
}

P. Brown, Chaucer at Work: the Making of the Canterbury Tales (London, 1994) offers first-rate practical advice on how to begin reading and making sense of Chaucer's text. A. Blamires, The Canterbury Tales (Basingstoke, 1987) provides a brief but extremely useful survey of critical approaches to the tales. H. Cooper, The Canterbury Tales (Oxford, 1989) is an excellent companion and handbook to the tales which considers the date, text, genre, sources, structure and themes of each of the tales. The same author's The Structure of the Canterbury Tales (London, 1983) is an enthusiastic appreciation of the literary achievement of the Canterbury Tales which will inspire any reader to re-open Chaucer's works.

\section{Chaucer: real-life observation versus literary convention}

M. McKisack's The Fourteenth Century (Oxford, 1971) still provides a usefulintroduction to the period whose readability belies its textbook format. See also J. A. F. Thomson, The Transformation of Medieval England, 1370-1529 (London, 1983). D. Pearsall, The Life of Geoffrey Chaucer (Oxford, 1992) is an excellent life of Chaucer which locates his works in their biographical context. J. M. Manly, Some New Light on Chaucer (New York, 1926) is the classic attempt to present Chaucer's work as referring to real-life characters; P. Brown and A. F. Butcher, The Age of Saturn: Literature and History in the Canterbury Tales (Oxford, 1991) is a more recent work which seeks to identify historical allusions in the Canterbury Tales. W. C. Curry, Chaucer and the Medieval Sciences (London, 1960; 2nd edition) is a good introduction to Chaucer's use of medieval science whilst J. Mann, Chaucer and Medieval Estates Satire (Cambridge, 1973) emphasises Chaucer's use - and adaptation - of traditional literary conventions.

\section{Monologic versus dialogic Chaucer}

There are now a number of introductions to the work of Mikhail Bakhtin although his discussions of the monologic and the dialogic text, carnival, Menippean satire and so on are easily accessible in Bakhtin's own works, particularly in his Problems of Dostoevsky's Poetics (Ann Arbor, 1973) and 
Rabelais and his World (Bloomington, 1984). On Gower, see the articles by Minnis and Porter in A. J. Minnis, ed., Gower's Confessio Amantis: Responses and Reassessments (Cambridge, 1983). For a portrayal of the Canterbury Tales as a monologic, conservative work, see P. A. Olson, The Canterbury Tales and the Good Society (Princeton, 1986). Dialogic readings of Chaucer are currently more popular, see W. E. Rogers, Upon the Ways: the Structure of the Canterbury Tales (English Literary Studies, 36; University of Victoria, Canada, 1986) and H. Cooper, The Structure of the Canterbury Tales (London, 1983). P. Knapp, Chaucer and the Social Contest (New York, 1990) and D. Aers, Chaucer, Langland and the Creative Imagination (London, 1980) emphasise the social and political implications of reading Chaucer dialogically. P. Strohm, 'Form and social statement in Confessio Amantis and the Canterbury Tales', in R. J. Pearcy, Studies in the Age of Chaucer, vol. 1 (Norman, 1979) contrasts the monologic Gower with the dialogic Chaucer.

\section{Allegorical versus humanist Chaucer}

Classic statements of the methods of 'patristic' or 'historical' criticism appear in D. W. Robertson's A Preface to Chaucer (Princeton, 1962) and his Essays in Medieval Culture (Princeton, 1970). B. F. Huppé, A Reading of the Canterbury Tales (New York, 1967) interprets the tales as a whole in terms of the Augustinian doctrine of charity. E. T. Donaldson, Speaking of Chaucer (London, 1977) offers a humanist perspective on Chaucer, a perspective which is brought to bear on the 'Nun's Priest's Tale' in D. Pearsall, The Canterbury Tales (London, 1985). D. Pearsall's Variorum edition of The Nun's Priest's Tale (Norman, 1984) includes an excellent survey of the critical debate on this tale. J. B. Allen The Ethical Poetic of the Later Middle Ages (Toronto, 1982) and G. Olson, Literature as Recreation in the Later Middle Ages (Ithaca, 1982) offer contrasting - but complementary - accounts of medieval views of the nature and function of literature.

\section{Misogynist versus feminist Chaucer}

For women's social position in medieval England, see S. H. Rigby, English Society in the Later Middle Ages (Basingstoke, 1995). A. Blamires (with K. Pratt, and C. W. Marx), Woman Defamed and Woman Defended (Oxford, 1992) is an invaluable anthology which illustrates the range of ways in which medieval writers could discuss feminine nature, whilst medieval views of women also figure prominently in the primary sources gathered together in R. P. Miller, Chaucer: Sources and Backgrounds (New York, 1977). Chaucer's views on women have been the subject of a number of books in recent years, each of which adopts rather a different approach. See, for instance, P. Martin, 
Chaucer's Women: Nuns, Wives and Amazons (Basingstoke, 1990), E. T. Hansen, Chaucer and the Fictions of Gender (Berkeley, 1992); J. Mann, Geoffrey Chaucer (London, 1991) and C. Dinshaw, Chaucer's Sexual Poetics (Madison, 1989).

\section{Conclusion}

The issue of validity in literary interpretation has been the subject of much debate amongst modern literary theorists. S. Fish, Is There A Text In This Class? (Cambridge, Mass., 1980) argues against the possibility of resolving such debates, E. D. Hirsch, The Aims of Interpretation (Chicago, 1976) offers a more traditional defence of the possibility of knowledge in interpretation, S. Collini, Interpretation and Overinterpretation (Cambridge, 1992) offers a variety of views on this issue, including those of Umberto Eco and Richard Rorty. 